\title{
FINANCIAL CRISIS AND ITS GENERAL IMPACT ON DEVELOPMENTS WITHIN THE BANKING SECTOR OF BOSNIA AND HERZEGOVINA
}

\author{
Sonja Tomash-Miskin, Banja Luka School of Economics, Kralja Alfonsa XIII, Banja Luka 78000, Bosnia \& \\ Herzegovina, sonjat984@gmail.com
}

\begin{abstract}
Since the last great crisis in the world, it can be said that it is a financial crisis with an impact on the banking sector of the economy, it can be said that it is a financial crisis that has directly affected the economy of many very heterogeneous countries in economic development.

The first characteristic is that stronger economies have suffered less from the consequences of the financial crisis (2008) from the economic and political environment.

Another characteristic would be that the last financial crisis in the world began to develop substantially in 2008. In addition, it affected the most developed countries and its influence was very quickly extended to underdeveloped economies and countries in transition.

The basis for starting the crisis was based on the real estate crisis, the leading economic power at the time, that is, the United States. From the territory of the USA, it spread very quickly to other countries, that is, a pronounced fluctuation in real estate prices, created on the basis of mortgage loans from banks, affected the economy of all countries.
\end{abstract}

Keywords: financial crisis, bank, economy, national economy.

\section{INTRODUCTION}

The last major financial crisis in the world is related to 2008. It had a large and deep coverage and it covered a large number of countries, both the most developed and developing countries.

The scientific approach regarding the great financial crisis is facing the facts that are related to the possible causes of the crisis, but also to the observed consequences that the crisis has left on the overall economy of the observed country. 
At the same time, the consequences of the crisis affect the necessity of changes that need to be made in order for the economic and banking systems of the observed countries to be more stable and resilient to the crisis that may occur in the not so distant future.

A special problem in the analysis of the financial crisis from 2008 is the fact that it has its own temporal and spatial dimension. It appeared in the most developed economy in the world at that time, the relationship in the United States. It essentially arose as a financial crisis in 2008 as a crisis related to the situation on the real estate market in the United States. On that occasion, there were violent and large changes in prices on the real estate market, which spilled over to other business sectors in that country and then to other countries.

Thus the impact of the financial crisis on a large number of economies in the world, and especially on countries affected by transition processes and economic reforms, has become essential.

In this paper, the author focuses on the situation in the transition economy, more precisely in Bosnia and Herzegovina, but the same experiences are almost identical with the business and the consequences of economic activities in other transition countries.

\section{GENERAL ATTITUDES IN THE LITERATURE REGARDING THE CAUSES OF THE FINANCIAL CRISIS (2008)}

The literature on the financial crisis from 2008 is numerous, and the warning that a crisis would occur was even before the official proclamation of the crisis. For example, the author Minsky laid the theoretical foundations of crisis generation in the early 1980s, and according to him, it appeared in 2008 [1].

A number of authors point out that the onset of the crisis in 2008 (primarily the mortgage crisis, which grew into a financial crisis) began in the year when the situation on the US real estate market led to a real uncontrolled rise in mortgage prices. Thus, in 2005, Nobel laureate Schiller warned of the possibility of inflating real estate price bubbles, as a kind of psychological epidemic, and of reducing credit conditions, which are indications of the collapse of the real estate market and shares [2].

On the eve of the crisis, an author such as Gramlich warned of the dangers posed by the rapid growth of the mortgage market [3]. At the same time, he pointed out that households that are mortgaged will almost certainly lose income at some point and fall into a debt crisis, i.e. they 
will not be able to repay loans. The same author points out that the primary goal of the nation is to avoid the domino effect to the economy as a whole.

McLean and Nocera, point out that there was a long-standing bad policy in government policy and their impact on the economy because the government promoted the housing boom and credit expansion through government policy, which ended in collapse [4] or the financial crisis.

Gary Gorton observes that too much self-confidence in conducting primarily government policy always precedes the financial crisis [5]. According to Gorton, asymmetric information is the main cause of race, panic and crisis. The attitude of banks and their creditors towards the given real state of the economy is different. As long as the bank's assets are well rated, while the credit rating is satisfactory, the bank's creditors are generally indifferent to the details of the bank's situation, because the owners of capital and state guarantees are able to amortize minor disturbances, even losses, in business. However, when a shock occurs, such as a drop in real estate prices (houses of residents who have taken out a mortgage loan), doubts about the value of a bank's assets and its solvency rise sharply and the market panics. In such circumstances, an increase in the bank's capital or an increase in government guarantees for the bank's liabilities would usually be sought [5].

Gorton points out that economists misunderstand financial crises, i.e. he is of the opinion that financial crises are inherent in the creation of bank debt used to conduct transactions, and that crises will recur more often and faster in the future if the government does not create intelligent regulations. Investing in real estate seemed like a completely safe investment, although authors like [6] point out that there was excessive self-confidence in terms of form, financial markets, credit expansion, rising prices and indebtedness, and expose the entire economy to great risks.

In many countries, the financial crisis was felt before 2008, so it is often possible to find in the literature that the crisis began in 2007. However, as this is the banking sector of Bosnia and Herzegovina, a country where the more serious blows of the crisis to the banking sector were felt in 2008. 2008 is the year that is considered as the reference year, where it is registered in statistical data as the year of the financial crisis, as well as in the public in the decisions of regulatory state institutions. 


\section{A MODEL FOR GENERATING A FINANCIAL CRISIS AND CONSIDERING THE IMPACT OF THE FINANCIAL CRISIS ON THE ECONOMIES OF COUNTRIES}

There are authors who talk about the real existence of a model for generating a financial crisis in the economy, especially in transition economies such as Bosnia and Herzegovina. The author highlights the views regarding the existence of a "Financial Crisis Generation Model" and describes five phases [7]:

1. displacement: this phase represents the investor's reaction to external change;

2. expansion (boom): the phase in which there is a sudden expansion of credit;

3. euphoria: a logical phase in generating a post-expansion crisis that leads to a misperception of risk and expected returns;

4. profit taking: the phase in which well-informed investors withdraw their stakes from the market;

5. Panic and breakdown (panic): a phase in which everyone is motivated to leave the market and in which there is a decrease in the value of all financial instruments, an increase in illiquidity and solvency of market participants.

The crisis of 2008 is a good example in which all the above phases can be identified in full.

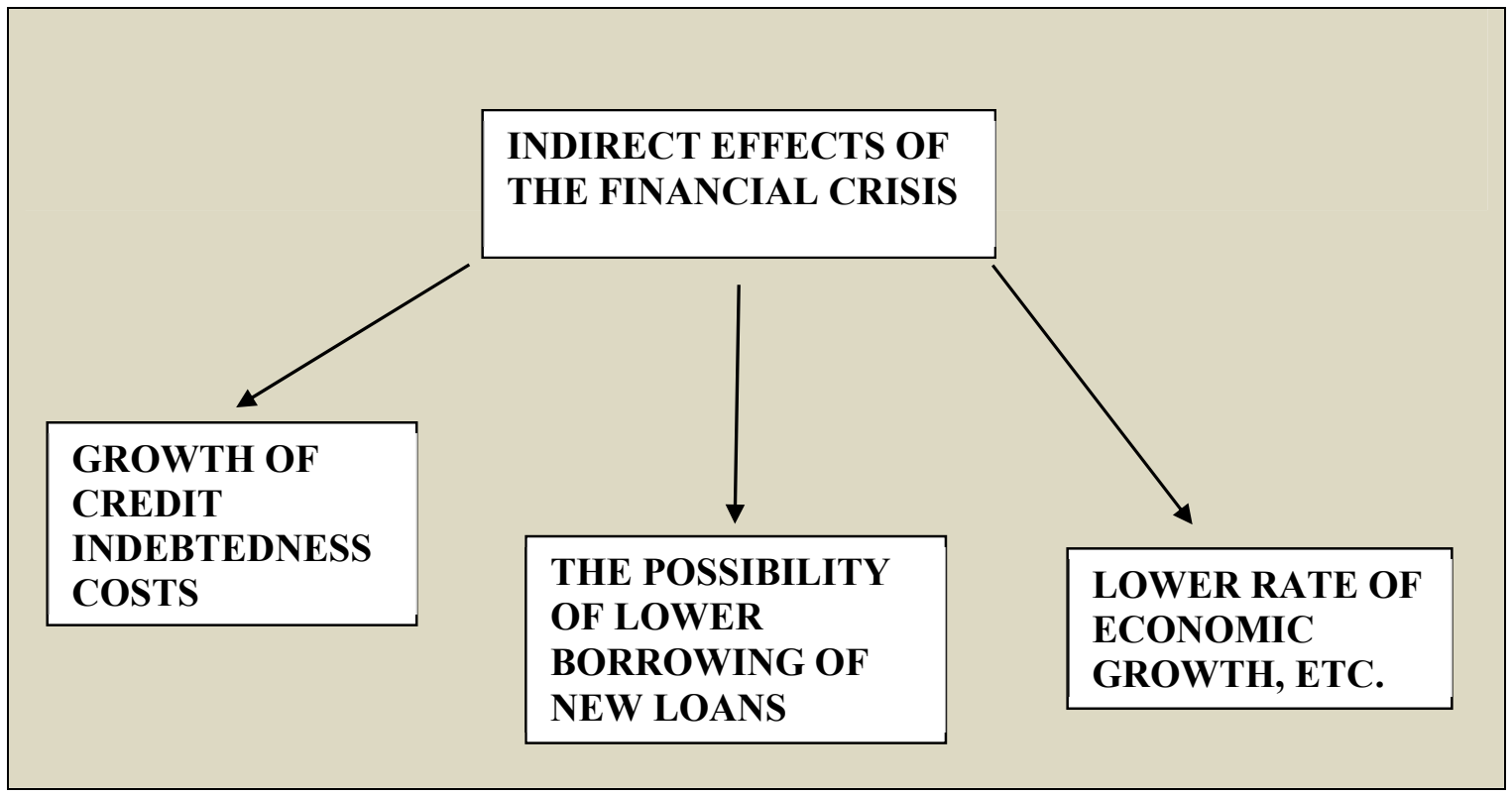

Fig. 1: Overview of indirect effects of the financial crisis in transition countries. 
Countries in transition have paid special attention to mitigating the financial crisis through:

1. trade balance (coverage of imports by exports for the most part),

2. degree of openness of the state (controlled opening of the economy),

3. sources of financing the trade deficit (direct foreign investments, remittances from abroad, loans from abroad),

4. inflation growth rates (moderate rate), exchange rate stability,

5. limited budget spending,

6. disciplined application of fiscal policy measures, etc.

The economy in these countries relies heavily on very heterogeneous legal entities [8-15], which largely determines the business of a large number of heterogeneous companies [16-24] whose existence requires positive business in continuity in order not to fall into losses.

\section{CONCLUSIONS}

The growth of the overall economy of the most developed countries was based on the growth of mortgage loans, which influenced the financial crisis in all parts of the world. The beginning of the financial crisis was largely transferred from developed economies to general crises in less developed countries, because they were strongly connected and relied on the economy of the most developed economies in the world.

In the concluding remarks, it should be noted that the consequences of inadequately conducted economic policy, especially in the most developed countries, have been felt since 2008. The impact of the financial crisis from developed economies spread very quickly to transition countries, such as Bosnia and Herzegovina.

At the beginning of the crisis, countries in transition had less opportunity for foreign borrowing with a simultaneous increase in interest rates globally. All this was accompanied by a situation of reduced real inflow of foreign direct investment. This has resulted in a reduction in real greenfield investments, as well as concessions.

The consequence of the above is leading to reduced business activity of a large number of companies. Inevitably, due to the reduction of investments, there was a process of reduction of real employment in the economy.

Finally, it should be noted that the reduction of total national production in a large number of heterogeneous countries and even in transition countries has directly affected the reduction of 
exports, reduction of remittances, reduction of budget revenues (taxes, contributions, customs, excise), reduction of personal and investment spending. which led to a decrease in overall economic activity in them.

Based on that, it can be pointed out that it is of great importance to immediately resolve the issue of financial crises in its infancy in order to reduce the growth of credit indebtedness in the country, and more importantly in a large number of companies that make up the country's economy.

\section{REFERENCES}

[1] Minsky, H. (1982). Can „It“" Happen Again//ISBN 978-0-332213-3.

[2] Shiller, R. (2005). Irrational Exuberance, Princeton University Press.

[3] Gramlich, E. M. (2007). Subprime Mortgages: America's Latest Boom and Bust, The Urban Institute Press, Washington.

[4] Gennaioli, N. \& Shleifer, A. (2018). A Crisis of Beliefs: Investor Psychology and Financial Fragility, Princeton University Press.

[5] Gorton, G. B. (2010). Slapped by the Invisible Hand: The Panic of 2007, Oxford University Press.

[6] Gorton, G. B. (2012). Misunderstanding Financial Crises - Why We Don't See Them Coming, Oxford University Press.

[7] Šoškić, D. (2009). Globalna finansijska kriza i Srbija: pouke i mjere//Svjetska ekonomska kriza i Ekonomska politika Srbije u 2009.godini, Ekonomski fakultet Beograd,Beograd.

[8] Sonja Tomaš-Miskin (2021). Doktorska disertacija, Strategijsko upravljanje performansama banaka Bosne i Hercegovine $\mathrm{u}$ uslovima finansijske krize, Univerzitet Union Beograd, Beogradska Bankarska Akdemija, Fakultet za bankarstvo, osiguranje i finansije.

[9] Popović, S., Novaković, S., Đuranović, D., Mijić, R., Grublješić, Ž, Aničić, J., Majstorović, A. (2017). Application of international accounting standard-16 in a public company with predominantly agricultural activities, Economic Research-Ekonomska Istraživanja, 30(1): 1850-1864.

[10] Mijić, R., Popović, S. (2016). Finansijsko Računovodstvo, Banja Luka: City print. 
[11] Majstorović, A., Popović, S., Volf, D. (2015). Teorija i politika bilansa, drugo izmenjeno i dopunjeno izdanje, Novi Sad: Feljton.

[12] Popović, S. (2014). Socio-ekonomski faktori ograničenja razvoja agrara, Monografija, Fimek, Novi Sad, Srbija.

[13] Popović, S., Ugrinović, M., Tomašević, S. (2015). Upravljanje menadžmenta poljoprivrednog preduzeća preko praćenja ukupnih troškova održavanja traktora, Poljoprivredna tehnika, 2: 101-106.

[14] Popović, S., Ugrinović, M., Tomašević, S. (2015). Management of Agricultural Enterprises by Means of Fair Financial Reporting in Accordance with International Standards of the Finance and Accounting Reporting, CDQM, Number 3: 24-30.

[15] Popović, S., Mijić, R., Grublješić, Ž. (2014). Interna kontrola i interna revizija u funkciji menadžmenta. Škola Biznisa, 1, 95-107.

[16] Popović, S., Tošković, J., Majstorović, A., Brkanlić, S., Katić, A. (2015). The importance of continuous audit of financial statements of the company of countries joining the EU, Annals of the „Constantin Brâncuşi”" University of Târgu Jiu, Economy Series, Special Issue, 241-246.

[17] Bojović, R., Popović, V., Ikanović, J., Živanović, Lj., Rakaščan, N., Popović, S., Ugrenović, V \& Simić, D. (2019). Morphological characterization of sweet sorghum genotypes acrossen vironments, The J. Anim. Plant Sci. 29(3).

[18] Popović, S. (2015). Implementacija heterogenih rizika u radu interne revizije, Revizor 69.

[19] Vitomir, J., Tomaš-Miskin, S., Ivić, M., Popović, S. (2020). Implementation of the Tender by the Municipal Service Administration from the Aspect of Management in the Municipalities of the Republic of Serbia, Lex Localis - Journal of Local Self-Government, 8, 3: $469-486$.

[20] Terzić, D., Popović, V., Malić, N, Ikanović, J, Rajičić, V., Popović, S., Lončar, M \& Lončarević. V. (2019). Effects of long-term fertilization on yield of siderates andorganic matter content of soil in the process of recultivation. The J. Anim. Plant Sci. 29(3).

[21] Radović, M., Vitomir, J. and Popović, S. (2019). The Importance of Implementation of Internal Audit in Enterprises Founded by the Republic of Serbia, Lex Localis - Journal of Local Self-Government, 17, 4: 1001-1011.

[22] Bjelica, B., Bakmaz, O., Mijić, R., Popović, S. and Popović, V. (2017). The implementation of heterogeneous risk to the company's operations and transition countries 
respecting the behavior of agricultural enterprises in the republic of Serbia. Annals, Economy Series, 3 .

[23] Radović, M., Vitomir, J. \& Popović, S. (2021). Impact of internal control in enterprises founded by local self-government units: the case of Republic of Serbia, Inzinerine Ekonomika-Engineering Economics, 32(1): 82-90.

[24] Ugrenović, V., Popović, V., Ugrinović, M., Filipović, V., Mačkić, K., Ljubičić, N., Popović, S. \& Lakić, Ž. (2021). Black Oat (Avena strigosa Schreb.) Ontogenesis and Agronomic Performance in Organic Cropping System and Pannonian Environments, Agriculture 2021, 11(1): 55. 